\title{
水ガラス系薬液注入固結砂の強度の耐久性 と浸透水圧の影響
}

\author{
加賀 宗彦 1 \\ 1 正会員 東洋大学教授 理工学部都市環境デザイン学科（テ350-8585 埼玉県川越市鯨井 2100） \\ E-mail: kaga@toyo.jp
}

\begin{abstract}
これまで著者は，静水養生した水ガラス系注入固結砂の経時的強度の予測に関して成果を上げてきた。 しかし，実際の注入改良地盤では浸透水圧や外力が作用した場合も想定され，これまでの予測は実務面で 適用できない場合も考えられる。そこで，本論文は浸透水圧を作用させた状態で供試体を養生できる試験 装置を作製し，注入固結砂の強度の経時変化を調查した。浸透水圧の影響は注入材の種類で異なった。ま たメスフラスコでゲル化した注入材を養生して物理, 化学的安定性に関連する注入材そのものの体積変化 とシリカの溶脱を約 9000 日(25 年)間調査した。その結果，体積変化やシリカの溶脱は一定期間を経過す るとほぼ停止した。また，少なくとも 25 年間はゲルの解重合はなかった。
\end{abstract}

Key Words : grout, durability, soil stabilization, compressive strength

\section{1. はじめに}

薬液注入による地盤改良は仮設工事などの短期的用途 から液状化防止工法など長期的用途へと使用範井が拡大 してきた. しかし，水ガラス系薬液注入固結砂は長期用 途に使用できるかどうかの耐久性に関し評価が定まって いない．また注入固結砂の耐久性などに直接影響を与え るゲル化した注入材(ホモゲル)そのものの体積変化やシ リカの溶脱などの物理・化学的な調查も少ない，そこで 著者は, 種類の異なる 3 種類の水ガラス系薬液注入材を 使用して上述の課題に関する研究を継続している. 使用 している注入材はアルカリ領域でゲル化する有機系注入 材, 有機系とは反対の酸性領域でゲル化する酸性シリカ ゾル系注入材およびシリカ粒径に特徴のあるコロイダル シリカゾル系注入材である. 本論文の理解を得るため最 初にこれまでの成果を簡単に述べる ${ }^{1) 44}$. 一般的に注入 固結砂の劣化は, シリカの溶脱が主な原因であると解釈 されることが多い. しかしゲル化した注入材(ホモゲル) そのものの物理・化学的な調査をした研究はほとんどな かったので, 当研究室は, 弱いゲルでも移動しないで体 積変化やシリカの溶脱を測定できるメスフラスコ法を考 案して研究に着手した. 約 4500 日までの調査で, ゲル化 した注入材(ホモゲル)そのものの体積変化やシリカの溶 脱は注入材の種類によって大きく異なる事を明らかにし た.また，各注入材のゲル構造も明らかでなかった。 そ こで研究に用いた 3 種類の注入材のゲル構造も明らかに した. これらの結果を利用してグリフスの理論をべース
に準理論的に注入固結砂強度の経時変化のメカニズムも 検討した ${ }^{3)}$. また, 注入固結砂に関しては, 長期強度の

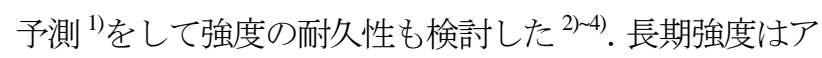
レニウスの式を利用した外挿法で予測し検討した．その 結果, 有機系注入固結砂と酸性シリカゾル系注入固結砂 は経時的に強度減少をする. しかし, 約 3000 日経過では 強度減少が止まりその後ほぼ一定の強度を保持すること を予測できた. コロイダルシリカ注入固結砂は, 他の注 入固結砂と異なり経時的に強度増加をする大きな特徵を 把握した. 以上がこれまでの結果であるが，ゲル化した 注入材(ホモゲル)の最大養生日数は約 4500 日であった. この時点では，いずれの注入材も体積変化とシリカの溶 脱は停止し安定していた. しかし，さらに長期にわたり ゲル化した注入材(ホモゲル)が安定するかどうかの確信 は得られていない，そこでゲル化した注入材(ホモゲル) の調査を継続した. 本論文は, 約 9,000 日目(25 年)の測 定を行いそのデータを得た. 前回報告した期間 4500 日の 2 倍である. 結果として調查した注入材 3 種類のゲルの 体積変化とシリカの溶脱はほぼ終息していることがわか った.この結果, 静水養生条件であれば少なくとも 25 年間はゲルの解重合がないことを結論できた. 次に, 注 入固結砂に関する検討をした. その研究課題の一つは, 追実験による長期強度予測の検証である．結果は予測の 傾向とほぼ一致した．しかし，これまでの注入固結砂強 度の経時変化は，静水養生による実験結果である，実際 の注入改良地盤では浸透水圧や外力が作用した場合も想 定され，静水養生による実験結果は実務面で適用できな 
い場合も考えられる，そこで，注入固結砂に浸透水圧を 作用させた場合の経時的強度変化に関するデータ ${ }^{5)}$ の蓄 積を行い，その評価をした. 浸透水圧は動水勾配 $i=1$ と 10 の浸透水圧を注入固結砂供試体に作用させた. 通常の 現場では見られない過酷な動水勾配である。結果は，注 入材の種類によって浸透水圧の影響で強度の劣化が進行 するタイプと影響を受けないタイプがあった. 本論文の 一連の研究結果は次の手順で報告する. 最初にゲル化し た注入材(ホモゲル)に関する検討．続いて，注入固結砂 の長期強度予測の検証. 最後に浸透水圧が作用した注入 固結砂の耐久性に関する検討をする.

\section{2. 使用材料の物性と実験方法}

\section{（1）使用材料の物性および供試体作製と養生方法}

注入固結砂供試体の作製には豊浦砂を使用した．砂の 土粒子密度 $\left(\rho_{s}\right)$ は $2.667 \mathrm{~g} / \mathrm{cm}^{3}$ である. 使用した注入材はゲ ル化の $\mathrm{pH}$ 領域および構造 ${ }^{2}$ が異なる 3 種類を使用した. アルカリ領域でゲル化する注入材はグリオキザールを反 応材とした有機系注入材, 非アルカリ領域からは酸性シ リカゾル系注入材を選定した. さらに，シリカ粒子を重 合で約 100 倍(直径約 10nm)大きく成長させたシリカ粒子 に特徵のあるコロイダルシリカゾル系注入材を用いた. それぞれの注入材の呼び名と物性を表-1 に示す. なお, 詳しい砂および注入材の物性については文献3)を参照さ れたい. 注入固結砂供試体の作製は内径 $5 \mathrm{~cm}$, 高さ $10 \mathrm{~cm}$ の透明アクリル円筒モールドを注入孔の付いた底板に載 せ, 円筒内には乾燥密度が $1.50 \mathrm{~g} / \mathrm{cm}^{3}$ となるように砂を入 れて, その後, 排水孔のある上板で密閉した. 次に, 水 を下方から浸透させ砂の間隙を飽和した. その後，水を 注入材に切替えて注入材が砂の間隙量の 2 倍排水される まで圧力浸透を継続した. 水は, 注入材でほぼ 100\%置 換されている ${ }^{3)}$. 上下板に設置されている排水孔のバル ブを閉めこの状態で 2 日間 $20^{\circ} \mathrm{C}$ 室内で養生をした. そ の後脱型してサランラップで包み供試体を水中養生した。 養生温度は $20^{\circ} \mathrm{C}, 40^{\circ} \mathrm{C}, 55^{\circ} \mathrm{C}, 65^{\circ} \mathrm{C}$ である. 室内養生は, $20^{\circ} \mathrm{C}$ 恒温恒湿室で養生をした. $40,55,65^{\circ} \mathrm{C}$ 養生は温度 制御のできる水槽で養生した，なお，注入固結砂供試体 作製方法の詳細は文献 1)〜4)を参照されたい.

\section{（2）浸透水圧養生実験装置と実験方法}

注入固結砂供試体に浸透水圧を作用させた状態で養生 できるように, 注入固結砂供試体は図-1 に示すモールド の中央に置き，その周りにはベントナイトを隙間がない ように詰めた．隙間が生じないようにベントナイトを詰 めるには，多少のテクニックが必要である。その方法を 簡単に説明する. 水を混ぜたベントナイトの硬さは，市
表-1 注入材の種類の呼び名とその物性

\begin{tabular}{|l|c|c|c|}
\hline 注入材の種類 & 呼び名 & $\begin{array}{c}\mathrm{SiO}_{2} / \text { 体積 } \\
\left(\mathrm{g} / \mathrm{cm}^{3}\right)\end{array}$ & $\begin{array}{c}\text { ゲルタイム } \\
(\mathrm{min})\end{array}$ \\
\hline \multirow{2}{*}{ 有機系 } & $\mathrm{A} 20$ & 0.203 & 10 \\
\cline { 2 - 4 } & $\mathrm{A} 15$ & 0.152 & 20 \\
\cline { 2 - 4 } & $\mathrm{A} 06$ & 0.060 & 120 \\
\hline $\begin{array}{l}\text { 酸性シリカゾル } \\
\text { 系 }\end{array}$ & $\mathrm{CH}$ & 0.114 & 240 \\
\hline $\begin{array}{l}\text { コロイダルシリカ } \\
\text { ゾル系 }\end{array}$ & $\mathrm{CSN}$ & 0.323 & 90 \\
\hline
\end{tabular}

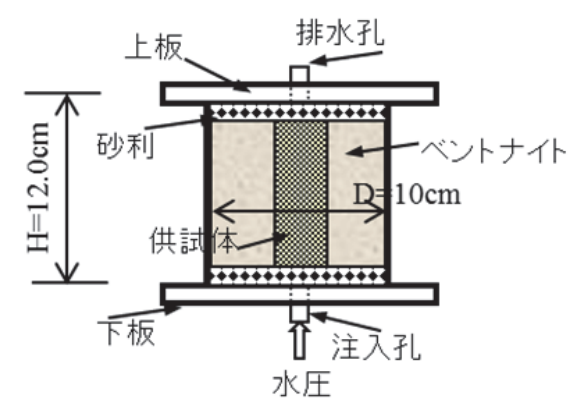

図-1 供試体の設置

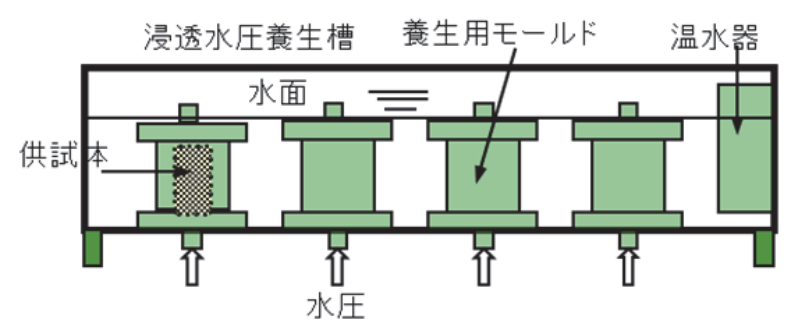

図-2 浸透水圧養生槽

販の工作用粘土とほぼ同じ状態にする. 次に注入固結砂 供試体とモールド間の腙間幅とほぼ太さが同じベントナ イトのロープを作る．このロープを注入供試体とモール ド間にとぐろを巻いて詰める. 高さが $3 \sim 4 \mathrm{~cm}$ 程度になっ たら，ドライバーの柄などを利用してとぐろ状に入れた ベントナイトを締固め付け，隙間がないようにする。 こ の操作を注入固結砂供試体の上部まで繰り返す。なお, モールド底面と上面には，浸透水が分散して給排水でき るように粒径約 $2 \mathrm{~mm}$ の砂利を敷いた。 モールドを組み 立てた後, 図-2 に示寸養生水槽に設置した. この水槽は, モールド注水孔と連結して浸透水圧がかけられるように 工夫してある．浸透水圧は注入固結砂供試体の下方から 作用させた. 水圧は動水勾配 $i$ が 1 および 10 となるよう な 2 通りで行った。 それぞれの水圧は $0.98 \mathrm{kPa}, 9.8 \mathrm{kPa}$ である. 動水勾配 $i=10$ は大深度地下 ${ }^{6}$ では実際に遭遇す るが，一般の耐久性を目的とした注入改良地盤では過大 と考えられる。 それでも耐久性に関する浸透水圧の影響 の把握は必要と考え実施した，なお，養生水槽の水温は 
$70^{\circ} \mathrm{C}$ ま゙上昇させることができるので, 促進養生も行っ た. 温度は $20^{\circ} \mathrm{C}, 40^{\circ} \mathrm{C}, 55^{\circ} \mathrm{C}, 65^{\circ} \mathrm{C} の 4$ 通りで行った. 以前の促進養生 ${ }^{1)}$ では, 最大温度 $70^{\circ} \mathrm{C}$ を採用していたが, 今回は養生水槽が大きいので大量の水が蒸発し，水の補 給に要する労働負担が大きいので養生水槽の水温を $5^{\circ} \mathrm{C}$ 下げて $65^{\circ} \mathrm{C} し し$ 所定の養生日数に達した供試体はモ ールドから取外し一軸圧縮試験を行った。一軸圧縮試験 はJIS A1216 : 1998 に準じて行った. 注入固結砂供試体 からの浸透水量は測定していない. なお，静水で養生し たものを静水養生，浸透水圧を加えて養生したものを浸 透水圧養生と呼ぶ。また，20ㄷで養生したものを標準養 生と呼ぶ. $20^{\circ} \mathrm{C}$ 以上の温度で養生したものを促進養生と 呼ぶ. 呼び名は組み合せて促進浸透水圧養生などと呼ぶ.

\section{（2）ゲル化した注入材 (ホモゲル)の経時的体積変化とシ リカの溶脱}

ゲル化した注入材(ホモゲル)そのものの化学・物理的 変化は注入固結砂の強度に影響を及ぼすと考えられる. そこでゲル化した注入材(ホモゲル)の経時的体積変化と シリカの溶脱を調査した.この実験にはメスフラスコに よる測定方法を考案した. 理由は，ゲル化した注入材(ホ モゲル)が体積減少をした場合，ゲルに含まれている水は 表面から排水される.そのため最初に表面から収縮し内 部はもとのままの状態の場合, ゲルは表面から割れてく る. したがって通常のノギス法や浸水させる浮力方法で 体積を測定するのは困難であった. メスフラスコによる 方法で既に 4500 日(12年)まで測定した結果は文献1)で発 表した.今回はその後も供試体を保管し約 9000 日(約 25 年)の測定を行いその結果について述べる. 実験に用いた メスフラスコはガラス製で体積は 300ml である.このメ スフラスコに注入材を約 $160 \mathrm{ml}$ 入れゲル化後メスフラス コ $300 \mathrm{ml}$ の目盛りまで蒸留水を満たし，20 ${ }^{\circ}$ 恒温恒湿室 で養生した。ゲルの体積は次のようにして求めた。

$$
\begin{aligned}
& V_{G}=300-\left(m_{G V}-m_{G}\right) / \rho_{w} \\
& V_{G}: \text { ゲルの体積 }\left(\mathrm{cm}^{3}\right) \\
& m_{G}: \text { ゲルメメスフラスコの質量 }(\mathrm{g}) \\
& m_{G V}: m_{G}+300 \mathrm{ml} \text { までの水の質量 }(\mathrm{g}) \\
& \rho_{w}: \text { 水の密度 }\left(\mathrm{g} / \mathrm{cm}^{3}\right)
\end{aligned}
$$

$300 \mathrm{ml}$ の目盛りまで入れた蒸留水は所定の日数になった 時，取り替えた．取り替えのため取り出した蒸留水から は，溶脱したシリカ量を測定した. シリカ量の測定はモ リブデン酸黄法で測定した.ただし 4500 日測定のみパッ クテストでシリカ量を測定した．パックテストの最小読 み取り值は $2 \mathrm{mg} / \mathrm{l}$ で水道水に含まれるシリカ量も読み取 れる. したがって溶脱シリカ量の判定に大きな障害がな いと判断した. 今回の約 9000 日測定は, シリカの溶脱が ほとんどないものと推測し，100 倍測定精度をあげて 0.02mg/l まで測定できるモリブデン酸青法測定器を使用

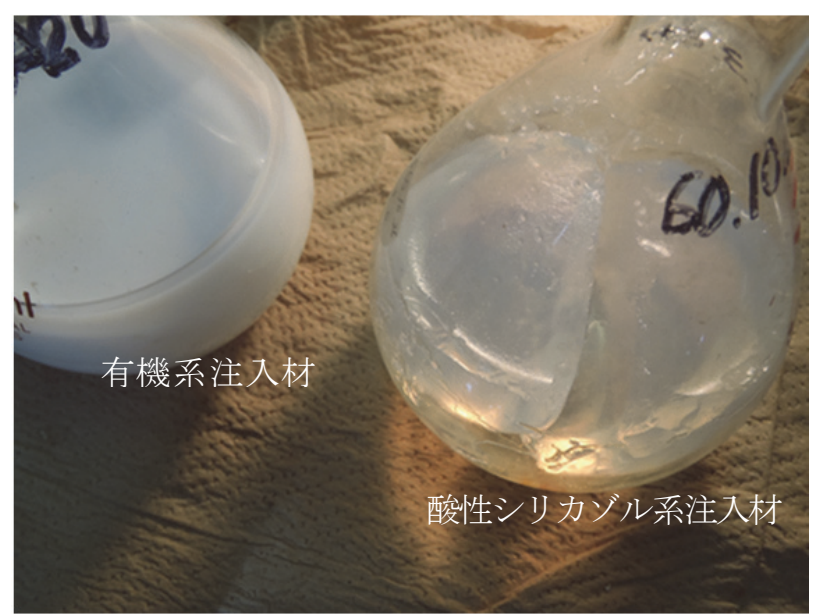

写真-1 約 9000 日養生の有機および酸性シリカゾル系注入材

した．なお，本論文のメスフラスコによる測定法は，ゲ 儿強度が弱く移動できない場合でもゲルの体積変化がで きる方法として考案したものである，ただ，この方法は ゲルと水の接触面積が変われば溶脱の量も変化するもの と考えられる．したがって，同じ実験を実施しても接触 面積が異なった場合, 経時的シリカ溶脱のグラフは変わ るかもしれない. ただし, 約 9000 日の測定で, ゲル化し た注入材(ホモゲル)の解重合の兆候は見られない。この 状態で溶脱量がほぼ一定になるまで測定している. した がって全溶脱量はほぼ正しいものと推定できる. なお, 酸性シリカゾルのゲルは 4500 日以前に写真-1 に示すよ

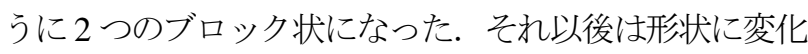
がなく, 9000 日経過現在も同じ 2 つ割れの状態である. なお，写真-1 は養生水取り替えのため養生水を排出した 時の写真である. 参考までに有機系注入材の様子も同写 真に示す.

\section{3. ゲル化した注入材 (ホモゲル)の経時的体積変 化}

約 9000 日養生したゲル化した注入材(ホモゲル)の体積 変化を，4500 日間調查した文献 1)のデータに追加した. それを図-3〜5に示す，それぞれの図の最終測点が今回 測定した約 9000 日(正確には 9305 日〜9669 日)の測点で ある. 最初に有機系注入材で $\mathrm{SiO}_{2}$ 濃度の大きい $\mathrm{A} 20$ 注 入材およびA20 注入材に比較して濃度がやや小さいA15 注入材の体積変化を考察すると, ともに約 40 日経過後ま でに約 5 6\%の体積変化をして, その後ほぼ一定となる. 40 日までの変化量は 9000 日の体積変化の約 $90 \%$ である. 今回の測点は 4500 日経過測点とほぼ同じ值で変化がな かった．有機系注入材とは反対の酸性領域でゲル化する シリカゾル系注入材は, 収縮期間が長く 1000 日までに約 


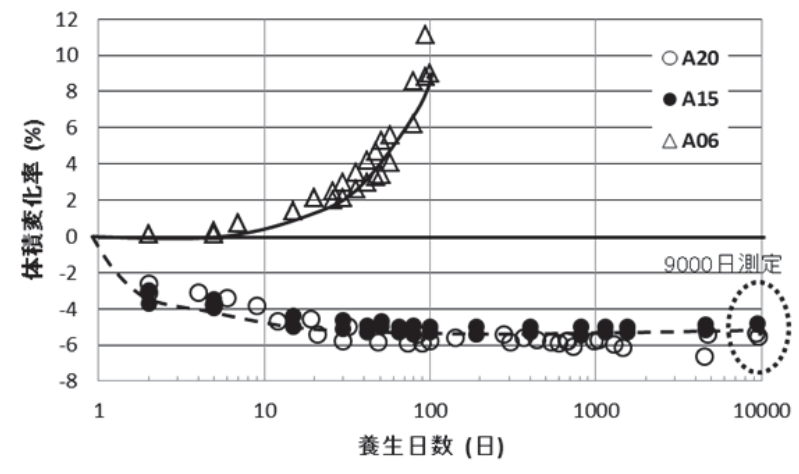

図-3 有機系注入材の体積変化

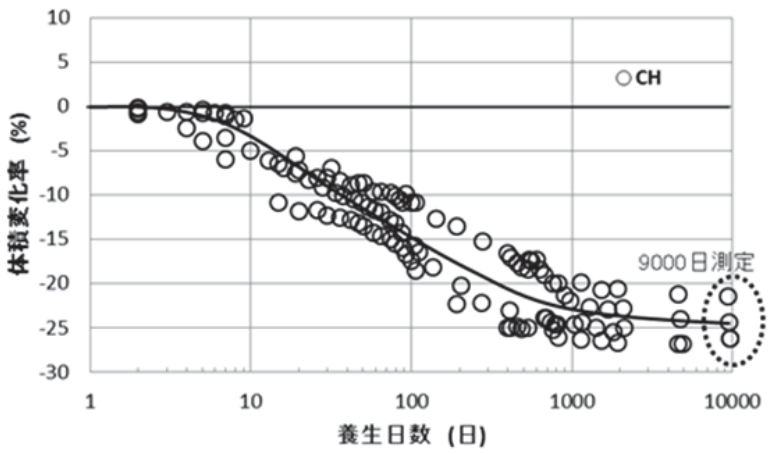

図-4＼cjkstart酸性シリカゾル系注入材の体積変化

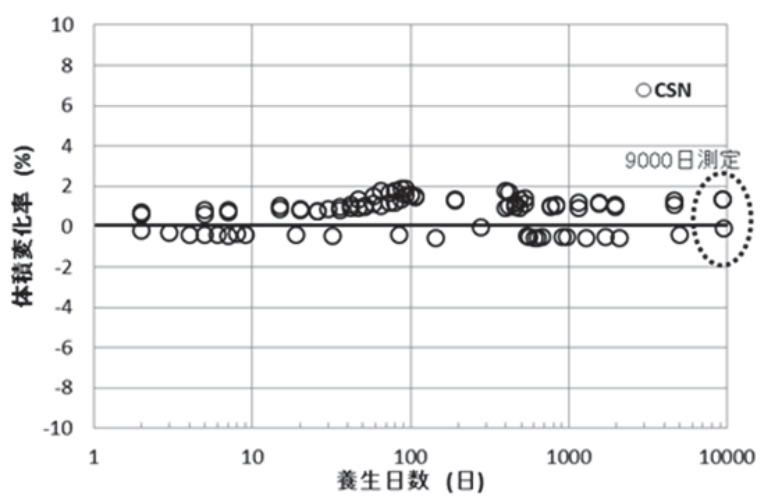

図-5 コロイダルシリカゾル系注入材の体積変化

23\%の体積减少をする.この体積変化は 9000 日の体積変 化の 95\%である. 1000 日以後 4500 日間は約 5\%の体積 変化をする. その後 9000 日間までの体積変化はほぼゼ口 となる. 酸性シリカゾル系注入材の体積変化は終息した と考えることができる．ただ酸性シリカゾル系注入材の 体積変化は有機系注入材に比較して大きい. 文献 2)によ れば有機注系入材のゲルの構造は短腺状ゲルのからみ合 いで，シリカゾル系注入材はガラス状である．体積変化 の違いはゲル構造に関連しているものと推測できる．最 後に図-5 のコロイダルシリカゾル系注入材の体積変化 を考察する. この注入材の経時的な体積变化は図-5に示
されるように 9000 日(25 年)経過後もほぼゼロである.コ ロイダルシリカゾル系注入材のゲル構造は粒状体が蜂の 巣状の間隙を持った構造 ${ }^{2)}$ となっている. 粒子に力が作 用した場合アーチ作用で簡単に変形できない構造になっ ているので, 体積変化が少ないものと考えられる.なお, 体積変化の詳細なメカニズムは文献 3)を参照されたい. これらの結果からゲルの安定性を推測する．温度が一定 で物理的な変化が無い静水状態でゲルを養生した場合, 体積変化が大きい有機系，シリカゾル系注入材でも少な くとも 9000 日(25年)経過でも安定を保つ. また酸性シリ カゾル系注入材のゲルは 2 割れをしたがその後の分割 は見られない，今回の実験から 3 種類の注入材は目視に よるゲルの解重合が無い事も明らかになった. ゲルの安 定性は今後もさらに継続するものと判断できる.

\section{4. ゲル化した注入材 (ホモゲル) からの溶脱シリ カ}

ゲル化した注入材(ホモゲル)からの長期的なシリカの 溶脱の測定は，化学的安定性を判定する一つの手段とな る.この安定性を見るためシリカの溶脱を約 4500 日間経 時的に調査し，そのデータを文献1)で報告した．今回は 9000 日(25 年)経過のデータを得た. 最初にメスフラスコ 養生液に溶脱したシリカ濃度と溶脱率で表した值を表2 に示寸。この表に示されるシリカ濃度と溶脱率は次に 示寸值である.

シリカ濃度 $(\mathrm{g} / \mathrm{ml})$ =メスフラスコ養生液 $1 \mathrm{ml}$ 当たり の溶脱シリカ量

シリカ溶脱率 $(\%)=($ 全溶脱シリカ量 $) /($ メスフラスコに 入れた全注入材シリカ量)

測定期間は前回測定した 4500 日から今回の 9000 日ま での約 4500 日ある. 結果は, 表に示寸ようにシリカ溶 脱率は，注入材の種類によらず 0.02 0.05\%の極微量な 溶脱である。溶脱濃度でみると同表に示寸ように飲料用 ミネラルウオーター程度のシリカ濃度である. このシリ カの溶解は，ゲルが蒸留水で養生されているため溶媒の 溶解力による影響と考えられる. 文献 1)に示した 4500 日溶脱率に 9000 日のデータを加算した累積溶脱率の結 果を図-6 に示寸. 同図に示寸縦軸はシリカの累積溶脱率 である. また, 横軸は養生経過日数である. 最終測点が, 今回の測定した值である.コロイダルシリカ系注入材は, 9000 日経過後もシリカの溶脱率はほぼゼロである. コロ イダルシリカの直径は，他の注入材に比べて大きいので 比表面積が小さくなり, 水との接触面積も小さくなる. これが溶脱の少ない理由の一つと言える．比表面積と溶 脱率の関係について詳しくは文献3)を参照されたい. 酸 性シリカゾル系注入材の溶脱率は1000 日経過で約2\%で 
表-2 注入材の種類と 4500 日から 9000 日間のシリカ溶脱量

\begin{tabular}{|l|c|c|c|c|}
\cline { 2 - 5 } \multicolumn{1}{c|}{} & \multicolumn{4}{c|}{ 注入材の種類 } \\
\cline { 2 - 5 } \multicolumn{1}{c|}{} & $\mathrm{A} 20$ & $\mathrm{~A} 15$ & $\mathrm{CH}$ & $\mathrm{CSN}$ \\
\hline $\mathrm{SiO}_{2}$ 濃度(mg/l) & 110.3 & 105.7 & 85.6 & 75.5 \\
\hline $\mathrm{SiO}_{2}$ 溶脱率\% & 0.044 & 0.045 & 0.042 & 0.018 \\
\hline
\end{tabular}

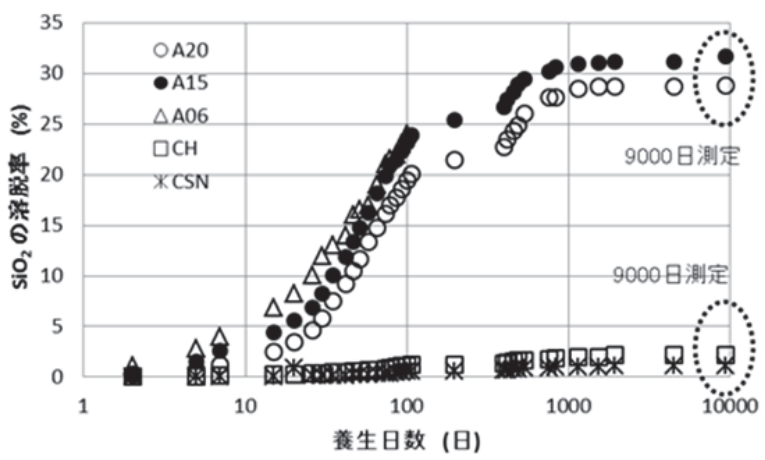

図-6 $\quad \mathrm{SiO}_{2}$ 溶脱率の経時変化

ある。しかし，それ以降は4500 日までは，ほとんど溶脱 が止まる.本論文はさらに長期の約 9000 日の測定をした. その結果，シリカの溶脱はほぼゼロであった。ゲル化し た注入材(ホモゲル)の安定性は保持されていることがわ かった. その理由はシリカゾル溶液の作成は酸性領域で 生成されるため未反応シリカはない．またゲル化した注 入材(ホモゲル)の解重合も生じていないためと考えられ る. 有機注入材をみるとシリカ濃度の大きい A20 で $23 \%$, A20 に比べて濃度の小さい A15 は 20\%の溶脱をして, そ の後の 9000 日の測定ではほぼ終息しているのがわかる. 有機系の未反応シリカは約 40\%あることは文献 1)で調 心゙られている. 有機系注入材の溶脱率はこの未反応シリ カ 40\%を超えていない. したがって溶脱シリカは未反応 シリカでゲルの解重合によるシリカの溶脱はないものと 判断できる. シリカ濃度が極端に小さいA06 は，100日 前後で小さな粒状態に分解して測定不可能となる，この 時点までのシリカ溶脱の経時変化はA15注入材と同じパ ターンである. 溶脱率はやや大きい. 今回の 9000 日測定 結果から水ガラスの配合が極端に小さいA06注入材を除 いて, 実験で用いた 3 種類のゲル化した注入材(ホモゲル) は, 静水養生であれば少なくとも 25 年間の解重合はない と判断できる.

\section{5. 長期予測強度の検証}

著者はこれまで温度促進法による強度の経時変化をア レニウスの外挿法で予測する方法を提案した ${ }^{1)}$. その手 法の理解を得るためアレニウスの外挿法による予測法を 簡単に説明する. 化学反応の速度式は次の式(1)で示され,

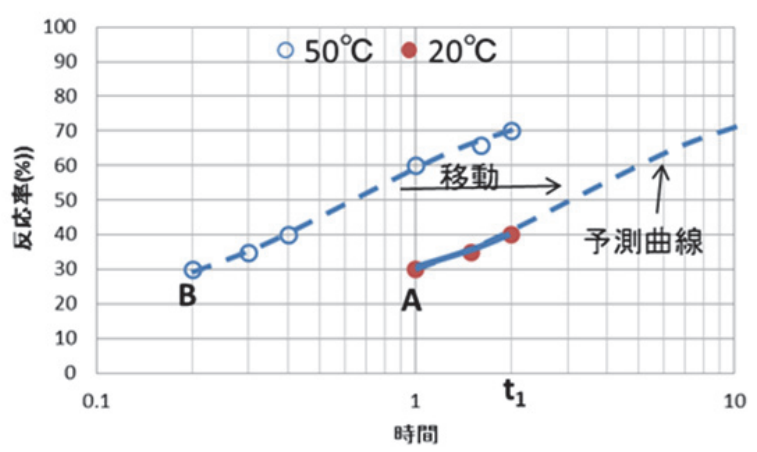

図-7 アレニウスの外挿法による予測法

また反応速度定数 $k$ は式(2)で示される ${ }^{7 \sim 9)}$.

$$
\begin{gathered}
\frac{d C}{d t}=-k C \\
k=A \exp \left(-\frac{E}{R T}\right) \\
\log t=\log \left[-\frac{1}{A} \log \left(\frac{C}{C_{0}}\right)\right]+\frac{E}{R T}
\end{gathered}
$$

$t$ : 時間, $k$ : 反応速度定数, $C_{0}$ : 初期濃度, $C$ : 濃度 $E:$ 活性エネルギー, $R$ : 気体定数, $T:$ 絶対温度 $A$ : 度数因子

式(1)，(2)から時間と反応率および温度の関係は式(3) となる. 式(3)の第一項の化学反応率が一定值になる時間 と温度の関係は, 化学反応率を $A$ 'で表すと次のようにな る.

$$
\log t=A^{\prime}+\frac{E}{R T}
$$

\section{$A^{\prime}$ : 化学反応率}

この式からアレニウスの外挿法による強度予測方法を 説明する. 例えば温度 $20^{\circ} \mathrm{C}$ (絶対温度 $T=292.3 \mathrm{~K}$ )で反応率 $A$ を 30\%にするための必要な時間 $t$ は 1 時間であったと する．この值は，反応率と時間の関係を示す図-7にプロ ットすると A 点となる. 温度を $50^{\circ} \mathrm{C}(T=323 \mathrm{~K})$ にした場合, 同じ反応率 $30 \%$ に必要な時間 $t$ は式(4)から小さくなり $\log (t)$ 軸上を移動した同図 B 点のようになる. ただし活性 エネルギー $E$ と気体定数 $R$ は変わらないものとする. A 点および $\mathrm{B}$ 点から同図に示す $t_{1}$ 時間まで $20^{\circ} \mathrm{C}, 50^{\circ} \mathrm{C}$ それ ぞれの温度で，時間と反応率の関係を測定してプロット すれば実線および点線のようになる．次に点線で示寸測 線の B 点を A 点まで移動し重ね合わせをすれば, 重ねあ わせの点線部分が $20^{\circ} \mathrm{C}, t_{1}$ 時間以降の予測反応率となる. また，式(1)は化学反応に比例するものであれば体積，表 面積，重量，強度変化も適用できる ${ }^{7) 99}$ ．当研究室では 注入固結砂の強度は化学変化の影響がある ${ }^{1)}$ と考え強 度の経時変化で整理した. この方法で 6,000 日(16 年)〜 
20,000 日(54年)までの予測を行いその結果は2000年に報 告した ${ }^{1)}$. 本論文は長期強度の予測值が正しいかを評価 するため, 促進養生および $20^{\circ} \mathrm{C}$ 標準養生による測点を追 加し検証した. 2000 年に発表した論文 1)の各日数におけ る全データの標準偏差の平均值は $64.6 \mathrm{kPa}$ であった. 今 回得た全データの標準偏差の平均值は73.7kPaであった. やや精度は低くなった．ただ，現在の注入改良地盤の設 計強度は, $\mathrm{N}$ 值に対応する統計的な図を参照して決めら れる場合が一般的である ${ }^{10)}$. さらに安全率を考慮して設 計される.レベルの高い設計方法はまだ少ない. したが って上述の標準偏差でも各種注入固結砂の長期強度の動 向を広義に見て, そのトレンドを把握する必要もあると 考えデータの整理を進めた. 次に, 実際の現場では浸透 水圧や外力を考慮しなければならない場合がある。そこ で本論文では，浸透水圧を作用させた場合の強度の経時 変化も調査した. 最初に静水養生の強度の経時変化の検 証について検討する.

\section{(1) 有機系注入材}

提案した強度の予測值が適切であるかどうかを調べる ため，新たに供試体を作製し検証した．特に長期強度の 予測值に注目した。 養生温度は $20^{\circ} \mathrm{C}, 40^{\circ} \mathrm{C}, 55^{\circ} \mathrm{C}, 65^{\circ} \mathrm{C}$ の 4 種類で行った. 今回得られたデータ(赤の*印)を文 献 1)のグラフに挿入して図-8 (a)〜 (d)に示す. 同図の 印およびアレニウスの外挿法を示す実線は文献1)で求め られたものである。この実線が予測強度を示す．なお， 同図(e)はすべてのデータの養生時間を $20^{\circ} \mathrm{C}$ 換算して プロットした図である, また同図(a)〜(d)には浸透水圧養 生による強度の経時変化を $\Delta, \square$ 印で示してある。この 強度についての考察は 6 章で検討する. 最初に図-8(a)に 示す $20^{\circ} \mathrm{C}$ 養生結果を見てみる. $20^{\circ} \mathrm{C}$ 養生は実験担当者が 変わった場合, 注入固結砂供試体の作製方法や注入材に 変化があるかどうかを確認するための目的もある．結果 は同図(a)に示すように前回のデータと比較し200日付近 でやや強度は小さい傾向を示す．実験担当者の特有の実 験テクニックに依存していることも考えられるが，その
明確な理由は判然としない. 強度の予測線は今回実施し た $40^{\circ} \mathrm{C}, 55^{\circ} \mathrm{C}, 65^{\circ} \mathrm{C}$ 促進養生強度によってもその信頼 性を確かめてみた。この強度の予測線は図-8 (b)(c)(d)に 黒の実線で挿入されている。 この実線はそれぞれの温度 促進倍率に合わせて挿入してある. 促進倍率は, アレニ ウスの外挿法と 6 章で後述する同形アレニウスプロット から求めた．その結果を表-3に示寸．挿人方法は，例え ば図-8(a)の標準養生強度の予側線は 30 日から始まって いる. $40^{\circ} \mathrm{C}$ 促進倍率は 10 倍なので 30 日/10 で 3 日か らスタートするように設定する. 図-8(b)〜(d)に示すよう に今回の実験で得た赤*印の測点は，予測線にほぼ沿つ た強度変化をしていると考える. 次に同図(a)〜 (d)に示し

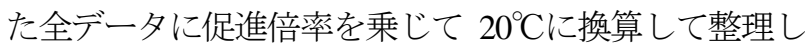
たものを図-8(e)に示す. 同図に示す青の $\triangle \mathrm{F}^{2} 40^{\circ} \mathrm{C}$, 緑 の $\square$ 印は $55^{\circ} \mathrm{C}$, 赤の $\diamond$ 印は $65^{\circ} \mathrm{C}$ 促進試験結果である.

なお，黒の○印は $20^{\circ} \mathrm{C}$ 標準養生結果である.これらの 測点はかなりのバラツキがあるが広義に解釈すれば文献 1)の予測実線にそってプロットされている。この結果 10,000 日(約 27 年)後には, 初期強度の $1 / 4$ まで強度低下 するが約 $500 \mathrm{kN} / \mathrm{m}^{2}$ の 強度は保持していることを予測 できる．実験で用いた注入固結砂供試体を観察すると， $20^{\circ} \mathrm{C}$ 最長養生日数 1,000 日，促進養生で 10,000 日にプロ

表-3 各注入材の温度と促進倍率

\begin{tabular}{|l|l|l|l|}
\cline { 2 - 4 } \multicolumn{1}{c|}{} & \multicolumn{3}{c|}{$\begin{array}{c}\text { 促進倍率 } \\
\text { (倍) }\end{array}$} \\
\hline $\begin{array}{c}\text { 温 } \\
\left({ }^{\circ} \mathrm{C}\right)\end{array}$ & A20 & $\mathrm{CH}$ & $\mathrm{CSN}$ \\
\hline 20 & 1 & 1 & 1 \\
\hline 40 & 10 & 3 & 10 \\
\hline 55 & 30 & 5 & 30 \\
\hline 65 & $36 *$ & $18 *$ & $40 *$ \\
\hline *は同形アレニュウスプロットから換算
\end{tabular}

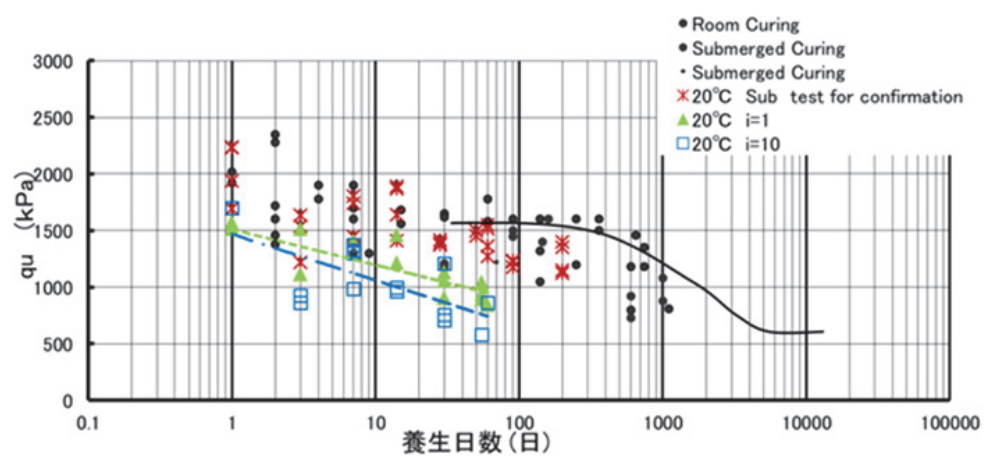

(a) A20 $20^{\circ} \mathrm{C}$ 標準養生

図-8 有機系注入材の強度の経時変化 


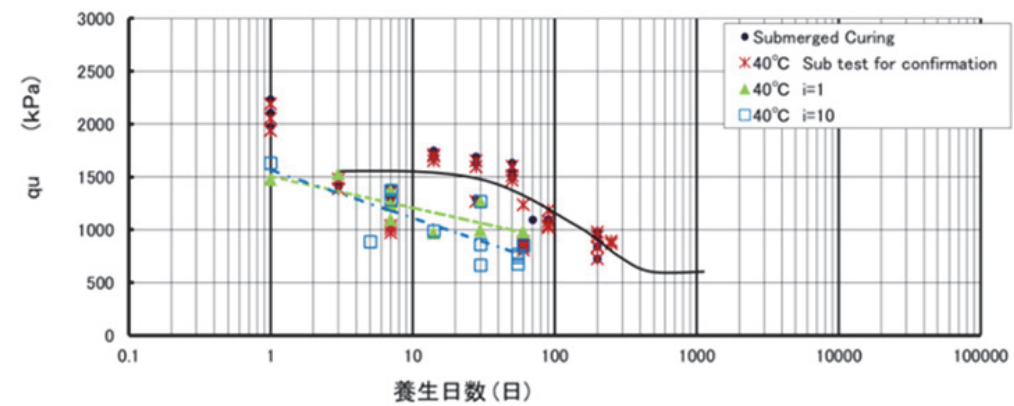

(b) A20 $40^{\circ} \mathrm{C}$ 促進養生

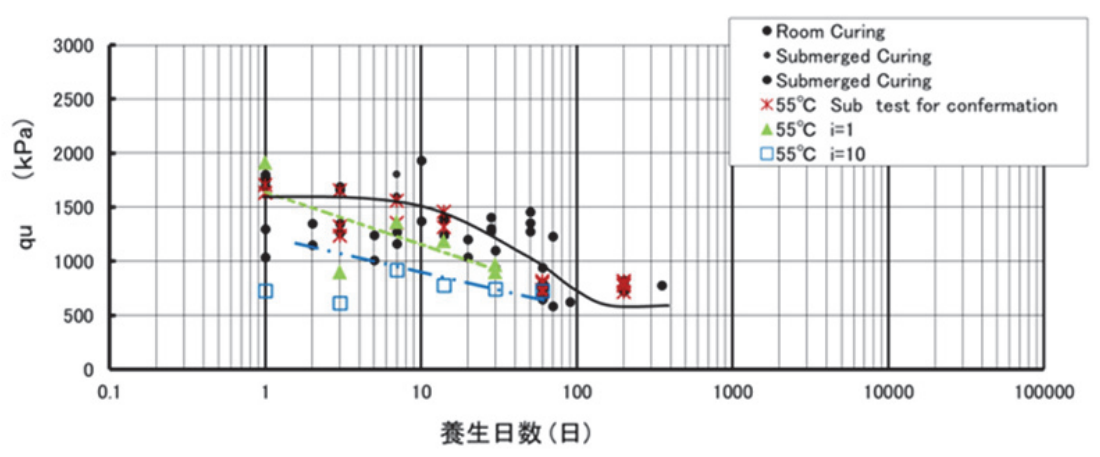

(c) A20 $55^{\circ}$ C促進養生

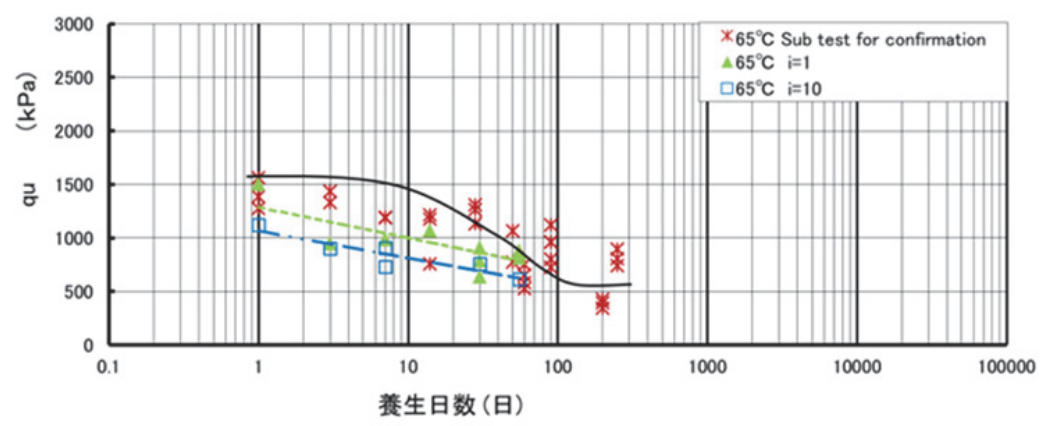

(d) A20 $65^{\circ} \mathrm{C}$ 促進養生

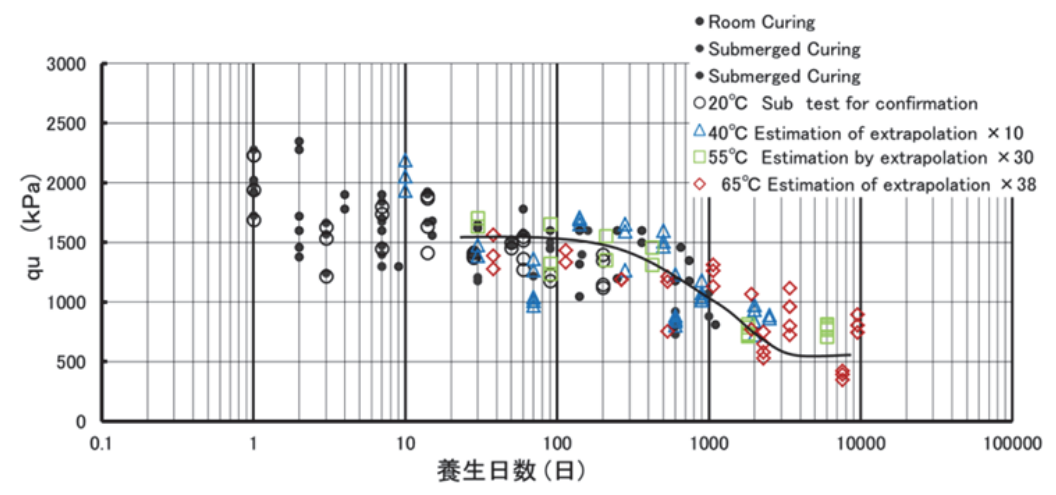

（e） A20 促進養生を $20^{\circ} \mathrm{C}$ 養生に変換

図-8＼cjkstart有機系注入材の強度の経時変化 (つづき) 


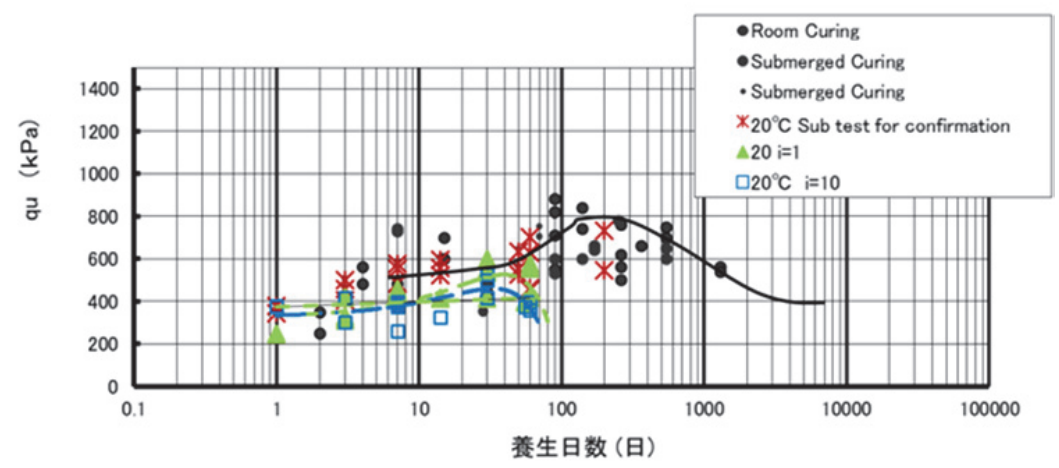

(a) $\mathrm{CH} 20^{\circ} \mathrm{C}$ 標準養生

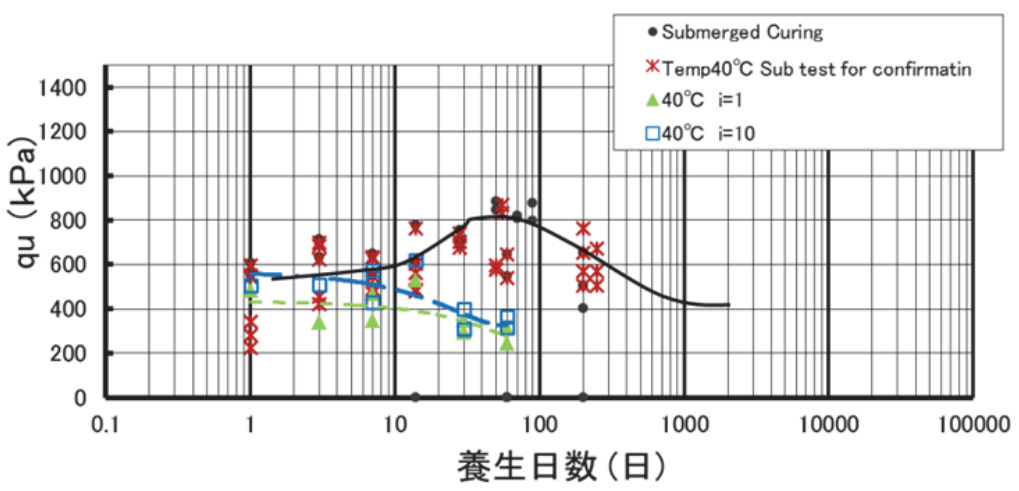

(b) $\mathrm{CH} 40^{\circ} \mathrm{C}$ 促進養生

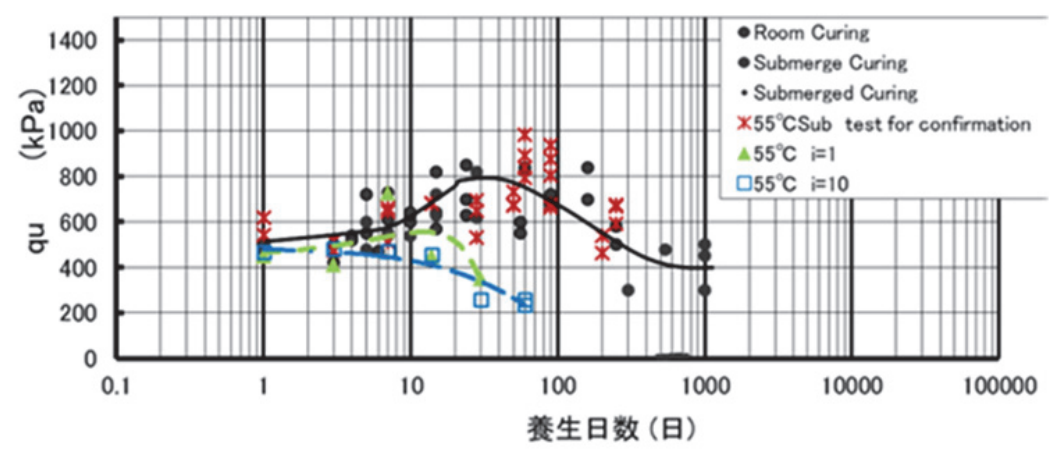

(c) $\mathrm{CH} 55^{\circ} \mathrm{C}$ 促進養生

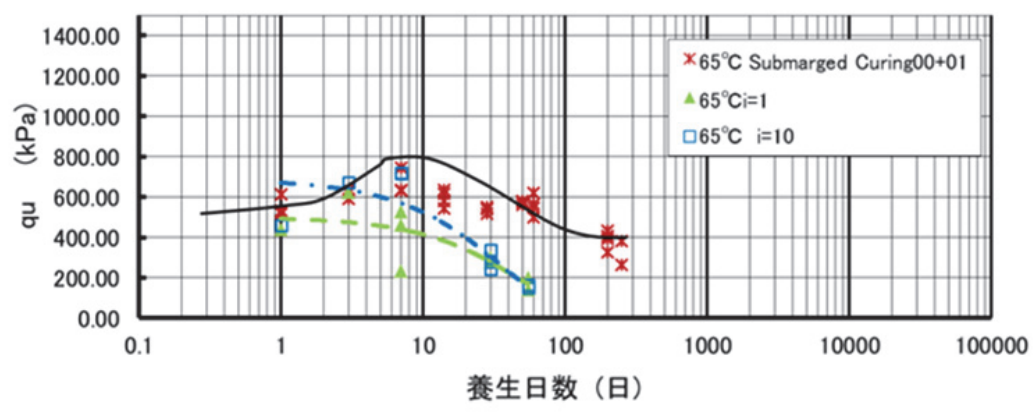

(d) $\mathrm{CH} \quad 65^{\circ} \mathrm{C}$ 促進養生

図-9＼cjkstart酸性シリカゾル系注入材の強度の経時変化 


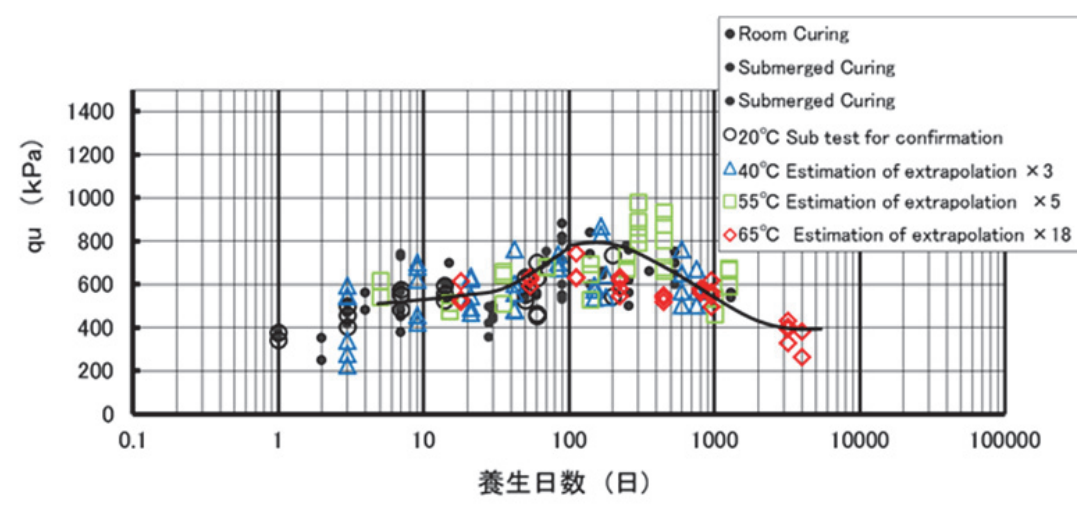

(e) $\mathrm{CH}$ 促進養生を $20^{\circ} \mathrm{C}$ 養生に変換

図-9 酸性シリカゾル系注入材の強度の経時変化 (つづき)

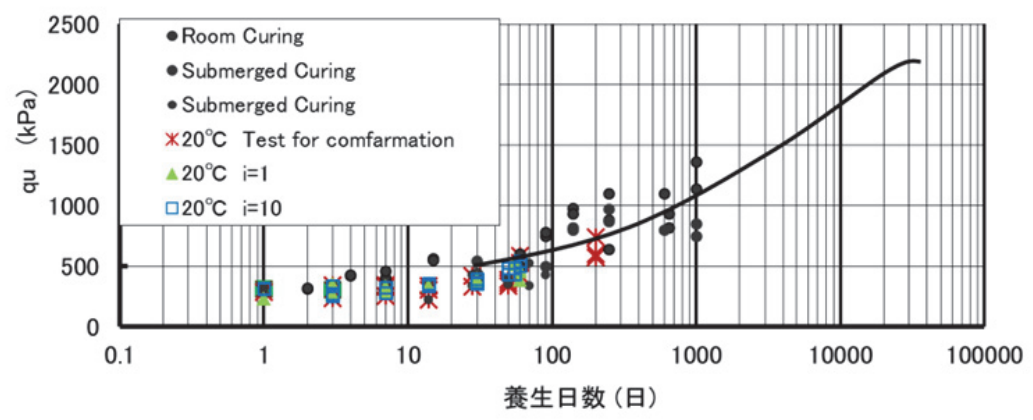

(a) $\mathrm{CSN} 20^{\circ} \mathrm{C}$ 標準養生

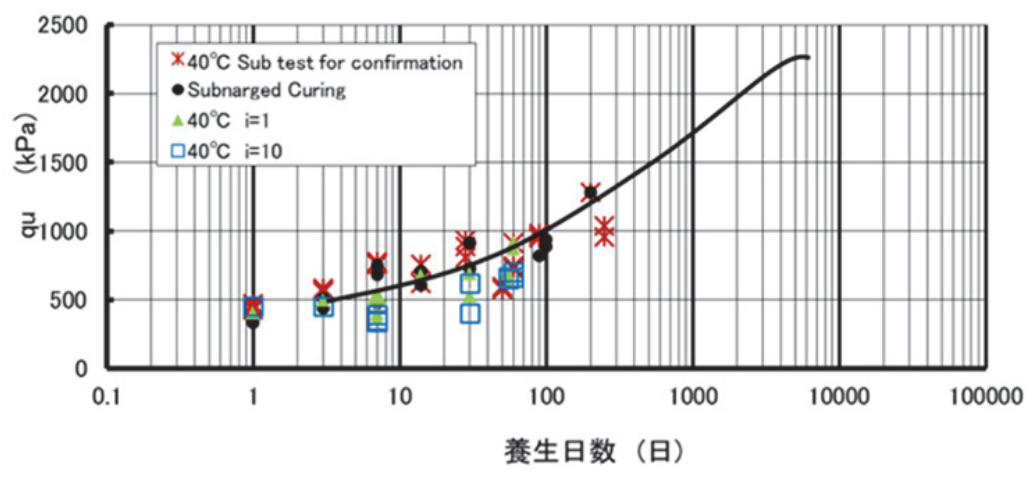

(b) $\mathrm{CSN} 40^{\circ} \mathrm{C}$ 促進養生

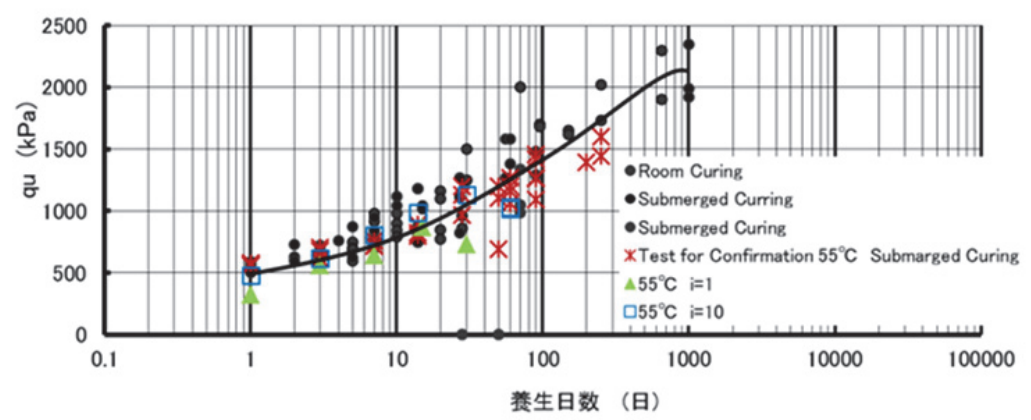

(c) $\mathrm{CSN} 55^{\circ} \mathrm{C}$ 促進養生

図-10＼cjkstart酸性シリカゾル系注入材の強度の経時変化 


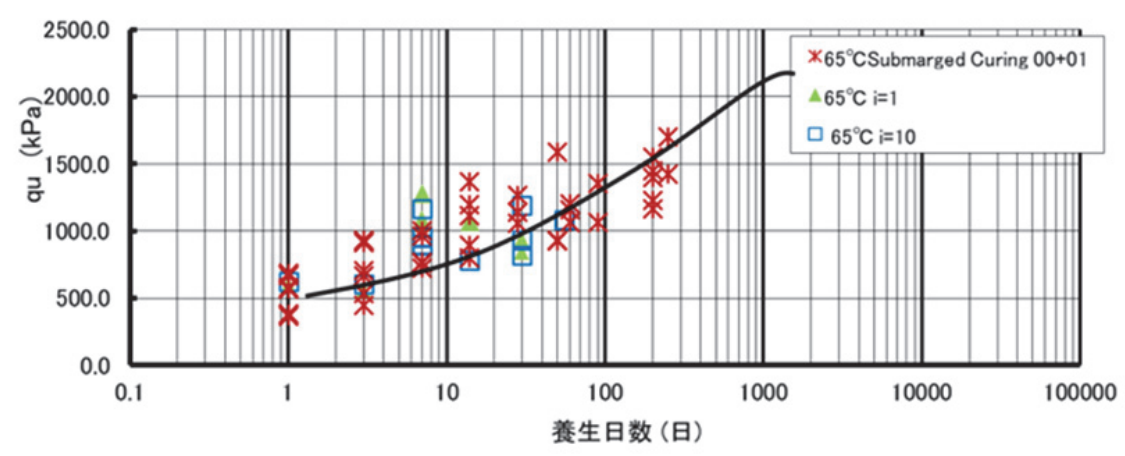

(d) $\mathrm{CSN} 65^{\circ} \mathrm{C}$ 促進養生

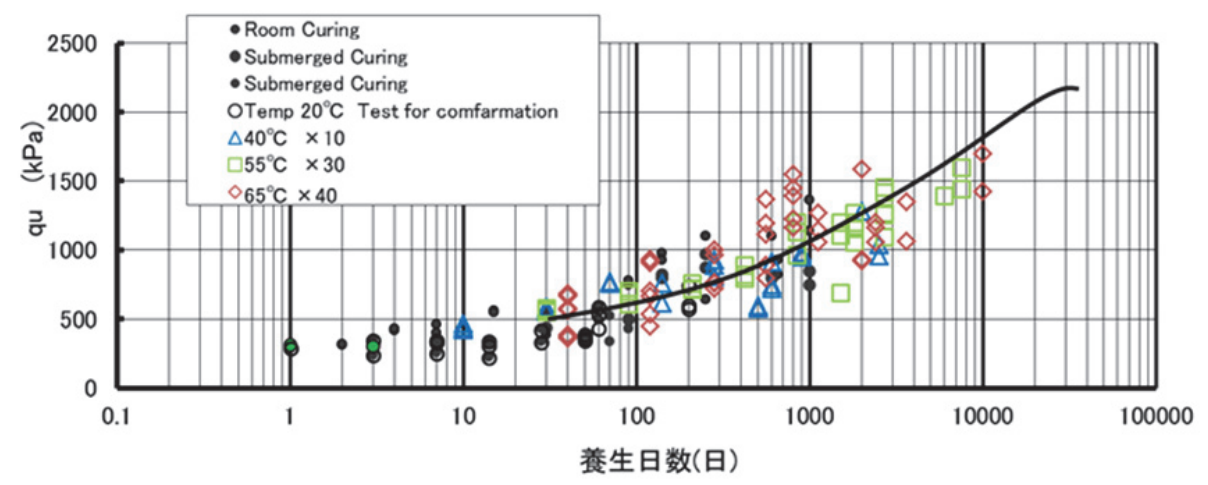

（e） CSN 促進養生を $20^{\circ} \mathrm{C}$ 養生に換算

図-10 酸性シリカゾル系注入材の強度の経時変化 (つづき)

ットされる注入固結砂供試体は，構成するゲル化した注 入材(ホモゲル)に解重合の兆候は見られない. 前述の 3, 4 章で述べたゲル化した注入材(ホモゲル)の体積変化お よびシリカの溶脱は, 養生 40 日前後までは 5 6\%の体積 変化をする. この体積変化は, 注入固結砂強度にどの程 度の影響を与えるかをグリフス理論をべースに求めると， 約 10\%の強度減少を生じることが推測された. これは既 に文献 3)で報告してある. 今回の約 9000 日経過の体積 変化やシリカの溶脱は 4500 日以降ほぼゼロである.これ より前回の調査 4500 日から体積変化やシリカの溶脱に よる劣化の進行はほとんどないものと推定できる。これ らの観点から本実験で使用した有機系注入材は静水の環 境下で使用した場合は, 約 $500 \mathrm{kN} / \mathrm{m}^{2}$ 程度の強度を 25 年 以上は保持できることが推定される. なお，注入材のゲ ル化はシロキサン結合によるものであるが，このシロキ サン結合はヤング率(弾性係数)に影響を与えることもす でに文献 3）で述べている．今回の実験結果を弾性係数 で整理することを試みたが，パソコンのソフトの変遷な どで応力ーひずみ曲線グラフのデータを見いだせず弾性
係数を求めることはできなかった.

\section{（2）酸性シリカゾル系注入材}

酸性シリカゾル系注入固結砂の強度の経時変化は, ピ 一クを持つ特徵がある.この特性は前述の有機系と同様 にグリフス理論をべースに準理論的に検討してある．ピ 一ク強度はヤング率に強く影響されていることなどが検 討されている. 詳しくは文献3)を参照されたい.このよ うな特徵を持つ注入材の強度の経時変化を予測する手法 も提案した. 本論文は，データをさらに蓄積してその手 法の評価をした. 評価は前述の有機系と同様な方法で行 なった. 図-9 (a)(b)(c)(d)は養生温度 $20,40 ， 55 ， 65^{\circ} \mathrm{C}$ の 実験結果である. 図中の記号は有機系を示した図-8 と同 じである. 赤の*印は今回のデータで, の印は文献1)に 示した測点である. 実線は予測值である. また，同図， 浸透水圧養生による強度の経時変化を示寸緑の $\triangle$ ，青の 口印の考察は，6 章で検討する. 図-9(a)〜(d)に示寸水印 を検討すると，ピーク強度付近ではやや下方にプロット される. しかしピーク強度から経過時間が長くなるに従 
いデータは予測線に沿ってプロットされている，そこで 全データの養生時間を $20^{\circ} \mathrm{C}$ 換算して検討してみた. そ の結果をプロットしたのが図-9(e)である. 図に示す青の $\triangle$ は $40^{\circ} \mathrm{C}$ ，緑の $\square$ は $55^{\circ} \mathrm{C}$, 赤の $>$ は $65^{\circ} \mathrm{C}$ 促進試験結 果である. 今回得られたデータはピーク強度付近で予測 線に対して下方にプロットされるものが多い. しかしピ 一ク強度以降の強度の経時変化はほぼ文献1)で予測した 実線に沿って変化をしている．この結果，5,000 日(約 13 年)後には，最大強度の $1 / 2$ まで低下するが $400 \mathrm{kN} / \mathrm{m}^{2}$ の 強度は保持していることが予測できた．有機系注入材と 同様に目視では，養生された注入固結砂供試体を構成す るゲル化した注入材(ホモゲル)に解重合は見られない. 酸性シリカゾル系注入材の体積変化とシリカの溶脱が, 強度の経時変化にどのような影響を与えるかは，既に検 討して報告してある ${ }^{3)}$.これによれば図-3に示した 1000 日前後で約23\%の体積減少は, 準理論的な検討で, 約 $45 \%$ の強度低下になる.しかし 1000 日経過後の注入固結砂強 度は 1 日養生強度に比較して逆に約 1.5 倍大きくなって いる. この結果, 体積変化は強度の経時変化に大きく影 響しないことが結論された. 1000 日経過後から9000日 までの体積変化はほぼ一定となる. また図-6に示すよう にシリカの溶脱もほとんど無い.これらの結果からも本 実験で使用した酸性シリカゾル系注入材は，静水の環境 下で使用した場合, 約 $400 \mathrm{kN} / \mathrm{m}^{2}$ 程度の強度を 13 年以上 は保持できることが検討できる. なお, ヤング率(弾性係 数)の経時変化は今回整理していない.

\section{（3）コロイダルシリカゾル系注入材}

コロイダルシリカゾル系注入材は，他の注入材と異な りゲル化した注入材(ホモゲル)の体積変化は, ほぼゼロ である．また，注入固結砂強度は，経時的に強度増加を する特徵がある.この予測法も文献1)で既に報告してあ る. 本論文は，前述と同様にこの予測法の評価をした。 今回の測定データを図-10(a)〜 (e)に示す. 同図(a)〜 (d) は養生温度 $20,40,55,65^{\circ} \mathrm{C}$ 順番で示してある. 図中 の記号は有機系と同様で○印は文献1)のデータ，*印は 今回得られたデータである. 予測線の挿入方法は前述の 有機系注入材と同じである. また, 同図(a)〜 (d)に示す $\Delta$, $\square$ 印の考察は 6 章で検討する. 図-10(a)〜 (d)に示す*印 のデータを見ると, 予測線のやや下方にプロットされる. 図-10(e)は促進倍率を用いて $20^{\circ} \mathrm{C}$ 標準養生に換算した全 測点をプロットした結果である. 同図に示す記号は前述 の有機系および酸性シリカゾル系と同じである. この図 の測点を考察すると, 本論文で示した測点は, 文献1)で 予測した黒の実線よりやや下方にプロットされる. その 理由は，実験担当者の技術的個性の影響とも考えられる が，有機系と同様に判然としない，今回のデータから長 期強度を予測すると 10,000 日(約 27 年)まで他の注入材と
は異なり，強度増加をしてその強度は約 $1500 \mathrm{kN} / \mathrm{m}^{2}$ とな る. 初期強度の約 5 倍である。結果として，本実験で使 用したコロイダルシリカゾル系注入材を静水環境で養生 した場合は，経時的に強度増加をして 10,000 日経過で $1500 \mathrm{kN} / \mathrm{m}^{2}$ 程度の強度となる.さらに強度増加は継続す ると予測できる．長期耐久性注入材としての使用は可能 であることが示唆される.

\section{6. 浸透水圧養生による強度の経時変化}

水ガラス系薬液注入による地盤改良の基本的な目的は， 地盤の補強と止水である。補強に関連した論文は多数発 表され成果を上げている ${ }^{11)}$ ，室内実験での養生条件は室 内養生か静水養生で実施されている。しかし実際の現場 では浸透水圧が作用した場合も想定される。 この浸透水 圧が作用した場合の研究は少ないが，文献 12)では懸濁 系グラウトでの成果を発表している. また文献13)では, 浸透水に見立てた流水中に注入固結砂供試体を置き注入 固結砂供試体からシリカが溶脱して強度減少することを 見いだし研究を進めている. しかし実際に浸透水圧を長 期的に作用させた実験例はほとんどなく成果も見られな い. その理由の一つは実験の難しさがある，例えば注入 固結砂供試体の止水実験は $10^{-8} \mathrm{~cm} / \mathrm{s}$ 程度の透水係数下 での測定が必要である. このため注入固結砂供試体と透 水用モールド間の止水(密着)が不完全な場合，または経 時的な注入固結砂供試体の微小な体積减少などの影響で 密着が不完全になった場合，注入固結砂供試体を通過し た浸透水なのか横漏れ水なのかの区別ができない. なお, 接触面のパイピングは均一浸透水のパイピングに比べて 2 倍発生じやすいことを文献 14)では，指摘している．こ のため, 経時的な浸透水量の測定は非常に困難である. この理由から本研究は浸透水量からの透水係数の経時変 化を調査するのは困難と考えた。 そこで，本実験では浸 透水量を測定しないが連続的に注入固結砂供試体に浸透 水圧を加え所定の時間が来たとき注入固結砂供試体の強 度を測定した。 これによって浸透水圧が作用した場合の 影響の一面は検討することができると考えた.ただし， 実験中浸透水の量が急に変化したときは注入固結砂供試 体側方からの漏れと考え，モールドの上板を外して注入 固結砂供試体周りのベントナイトが密着するように上か ら押さえつける操作をした，なお，実験は特殊な装置を 作製して温度促進浸透水圧養生も実施した。温度促進に よる養生中の注入固結砂供試体の含水比は 2～3\%の変 化で大きな変化はなかった，その代表測定例を図-11 に 示す。この図に示されるように静水養生と浸透水圧養生 の含水比はほぼ同じである，温度促進養生による乾燥の 影響はないと判断できる．なお，本実験は浸透水の採取 


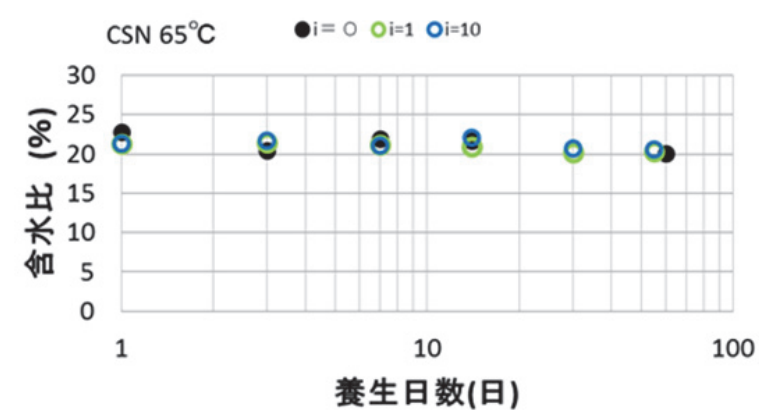

図-11 CSN 浸透水圧促進養生注入固結砂供試体の含水比

をしていないので浸透水圧によるゲルの化学的解重合の 分析は実施できなかった。

\section{(1) 有機系注入材}

前述の図-8(a)〜 (d) に浸透水圧を作用させた試験結果

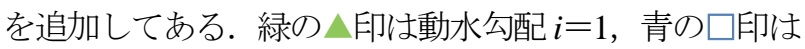
動水勾配 $i=10$ の浸透水圧を作用させた結果である. 図 に示されるように浸透水圧を作用させた注入固結砂供 試体の強度は, 静水養生注入固結砂供試体に比較して養 生日数が同じであれば小さいことが示されている. 図中 の緑の点線および青の一点鎖線はそれぞれの測点を最 小二乗法で整理し挿入した線である. 経過日数とともに 強度は減少寸る関係にある. これらの図から浸透水圧養 生による注入固結砂強度は, 標準養生に比べて小さくな ることがわかる.これは浸透水圧の影響によるものと推 測できる.この浸透水圧による影響を強度劣化速度の観 点に立って検討するため, 同形アレニウスプロットで整 理してみた. 前述のアレニウスの式(2)を $\log$ で表すと次 のように示される.

$$
\log k=\log C-\frac{E}{R T}
$$

$k$ : 反応速度定数, $C$ : 定数, $E$ : 活性エネルギー

$R:$ 気体定数, $T:$ 絶対温度

反応速度定数 $k$ は, 前述したように体積, 重量, 面積, 強度など化学反応速度に比例するものであれば代用でき

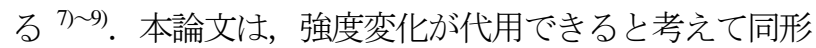
アレニウスプロットで整理してみた。 この方法は強度の 変化速度を対数表示の綐軸にとり養生温度は絶対温度に 変換してその逆数 $(1 / T) を$ 横軸にプロットしたものである. 一般的に同形アレニウスプロットは予測法に利用される. 例えば $55^{\circ} \mathrm{C}, 65^{\circ} \mathrm{C}, 75^{\circ} \mathrm{C}$ 促進養生で $q_{u} / 2$ になる時間と 強度の変化速度を求め対数の縦軸に強度の変化速度, 横 軸には絶対温度の逆数を取りそれぞれの測点をプロット する. これらの測点を直線で結びその延長線上の $20^{\circ} \mathrm{C}$ 標 準養生での強度変化速度を読夕取り，この速度から $q_{u} / 2$ になる時間を予測することができる，このように一般に
は，ある強度の劣化または増加するまでの時間の予測に 使用される. 本研究は静水養生と浸透水圧養生との養生 条件の違いで劣化(強度変化)速度が異なるかどうかを見 るため同形アレニウスプロットを利用した. 強度の変化 速度は次のように求めた。

強度の変化速度 $(\mathrm{kPa} / \mathrm{day})=\left(q_{u} / 2\right) / t_{0.5}$

$q_{u}$ : 初期強度

$t_{0.5}: q_{u} / 2$ になるまでの日数

この方法で静水養生および浸透水圧を作用させた養生温 度 $20^{\circ} \mathrm{C}, 40^{\circ} \mathrm{C}, 55^{\circ} \mathrm{C}, 65^{\circ} \mathrm{C}$ 強度の変化速度を求め, そ の結果を図-12 に示寸. 青の四印は文献 1)で示した 20, $40,55,70^{\circ} \mathrm{C}$ 静水養生で $q_{u} / 2$ になった場合の測点である. 図中の点線と一点鎖線は養生温度に対応寸る動水勾配 $i=1 ， 10$ を作用させて $q_{u} / 2$ になった時の変化速度をプロ ットした測点を最小二乗法で整理した線である。 それぞ れの相関係数 $R$ は表-4 に示寸. 図-12 に示されるように 動水勾配が作用すると強度の変化速度が大きくなる。 し たがって初期一軸圧縮強度 $q_{u}$ が $q_{u} / 2$ に劣化するまでの時 間は動水勾配の大きさに反比例する. この結果, 動水勾 配が大きくなると劣化の速度も速くなることが示唆され る.これらの結果から有機系注入材の強度の劣化は, 浸 透水圧に影響されるものと推測できる. 図-12 から動水 勾配 $i=1,10$ が作用した場合 $q_{u} / 2$ に減少するまでの時間 は， $20^{\circ} \mathrm{C}$ 標潐養生の比較で，それぞれ約 10 倍，約 50 倍 速くなると予測される.

\section{(2) 酸性シリカゾル系注入材}

前述の図-9(a)〜 (d)には酸性シリカゾル系注入固結砂

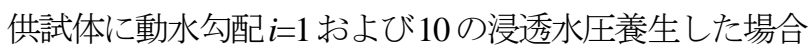
の強度の経時変化をプロットしてある. 図中の記号は上 述の(1)と同じである. 図に示されるように浸透水圧を作 用させた注入固結砂供試体の強度は，静水養生注入固結 砂供試体に比較して養生日数が同じであれば有機系注入 材と同じように小さくなることが示されている.これか ら浸透水圧は強度の劣化に影響を及ぼすもの考えられる。 図中の緑の点線および青の一点鎖線はそれぞれの測点を 最小二乗法で整理して挿入したものである. 次に有機系 注入材と同様に浸透水圧による影響を見るため同形アレ ニウスプロットで整理してみた. 図-13 の縦軸は $q_{u} / 2$ に なるまでの強度の変化速度である. 横軸は絶対温度の逆 数(1/T)である. 青のロ印は文献 1)で示した 20，40，55, $70^{\circ} \mathrm{C}$ 静水養生の $q_{u} / 2$ になった時の強度の変化速度求めて その值をプロットした測点である．また図中の点線と一 点鎖線は, 動水勾配 $i=1,10$ の浸透水圧を作用させ $q_{u} / 2$ になった強度の変化速度を図-9(a) (d)より求め, その測 点をプロットして最小二乗法で整理したものである. 図 に示されるように動水勾配が作用すると強度の变化速度 が大きくなる． $20^{\circ} \mathrm{C}$ 標準養生と比較した場合，動水勾配 
表-4 アレニウスプロットの相関係数 R

\begin{tabular}{c|c|c|c|c|}
\multicolumn{1}{c|}{} & \multicolumn{1}{|c|}{ 動水勾配 } & A20 & CH & CSN \\
\hline \multirow{3}{*}{$\mathrm{R}$} & $\mathrm{i}=0$ & 0.971 & 0.953 & 0.983 \\
\cline { 2 - 5 } & $\mathrm{i}=1$ & 0.856 & 0.934 & 0.983 \\
\cline { 2 - 5 } & $\mathrm{i}=10$ & 0.83 & 0.618 & 0.983 \\
\hline
\end{tabular}

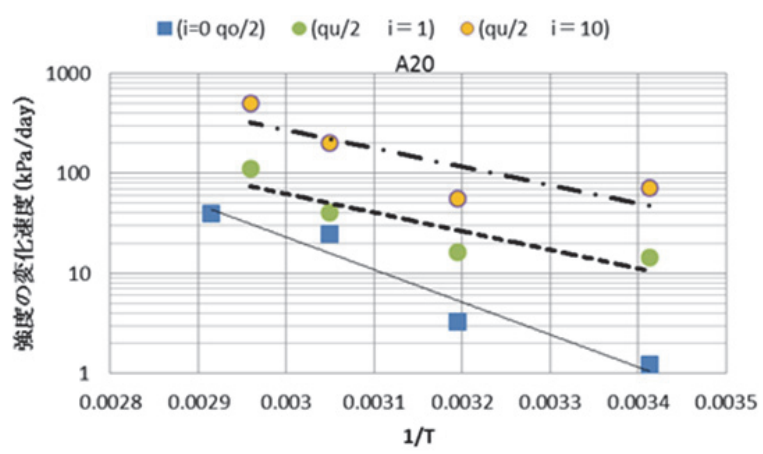

図-12 A20 同形アレニウスで整理した強度の変化速度

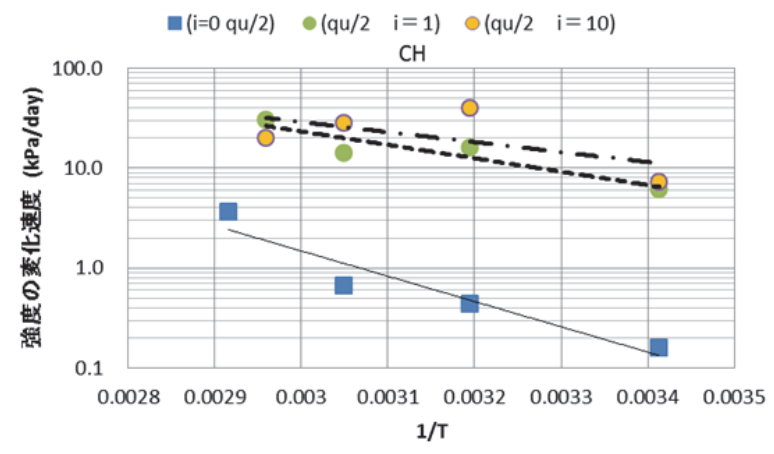

図-13 CH 同形アレニウスで整理した強度の变化速度 $i=1,10$ が作用した時，それぞれ $q_{u} / 2$ に減少するまでの 時間は，平均で約 40 倍，66 倍速くなる.この結果，浸 透水圧はシリカゾル系注入材の強度の劣化に影響するも のと推測できる.

\section{(3) コロイダルシリカ系注入材}

前述の図-10 (a)〜 (d)はコロイダルシリカゾル系注入 材を用いた試験結果である，本論文は，この図に浸透水 圧を作用させた試験結果をプロットした．図中の記号は 前述の(1) と同じである. 養生温度 $20^{\circ} \mathrm{C}, 40^{\circ} \mathrm{C}, 55^{\circ} \mathrm{C}, 65^{\circ} \mathrm{C}$ のそれぞれの図を見ると予測線のやや下方に示されるが， 静水養生とほぼ同じく時間の経過とともに強度が増加す る. 有機系注入材や酸性シリカゾル系注入材と異なり浸 透水圧を受けても強度の劣化は見られない，異なった温 度による促進浸透水圧養生強度を連続的に見るため, $20^{\circ} \mathrm{C}$ 換算して $20^{\circ} \mathrm{C}$ 標準養生強度の予測図に全点をプ ロットしてみた. 促進倍率は前述の表-3 に示す通りであ る. 結果は, 図-14 に示す. なお, 静水での促養生 $40^{\circ} \mathrm{C}$, $55^{\circ} \mathrm{C}, 65^{\circ} \mathrm{C}$ 測点は，図が煩雑になるためプロットして いない. 図中の $\Delta, \Delta, \Delta, \Delta$ 印は動水公配 $i=1$ の浸透 水圧が作用した $20 ， 40 ， 55 ， 65^{\circ} \mathrm{C}$ 結果である。動水勾 配 $i=10$ を作用させた浸透水圧養生試験結果は四角印で 示す．温度の違いは色分けをしてם，口，ロ， 口印で示 し，それぞれ 20，40，55，65ㅇ C結果である. 結果とし てコロイダルシリカゾル系注入材は動水勾配 $i=1,10$ の 浸透水圧が作用すると予測值のやや下方にプロットされ る.ただ，経時的強度の増加は見られる. この図からコ ロイダルシリカゾル系注入材は，他の注入材と異なり浸 透水圧が作用しても経時的強度の劣化がない.この結果 から判断すると浸透水圧が作用した実際の現場でも長期 耐久性が期待できる注入材と考えられる．なお，参考ま

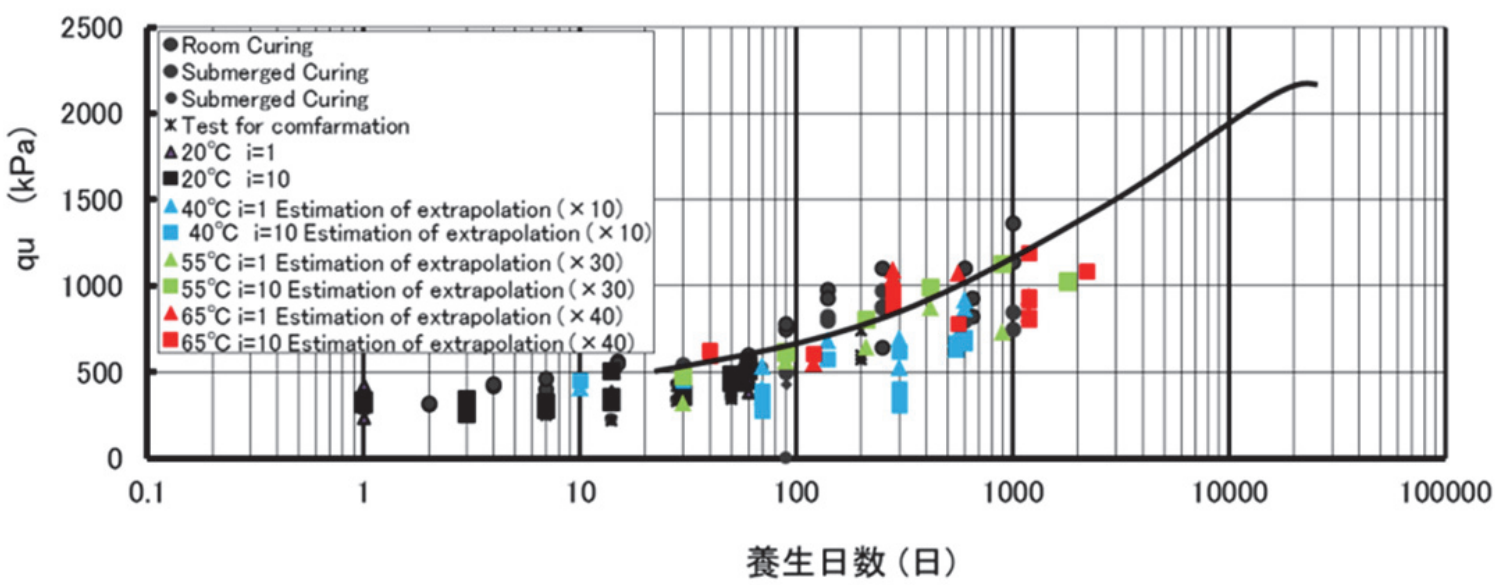

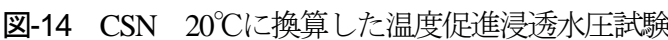




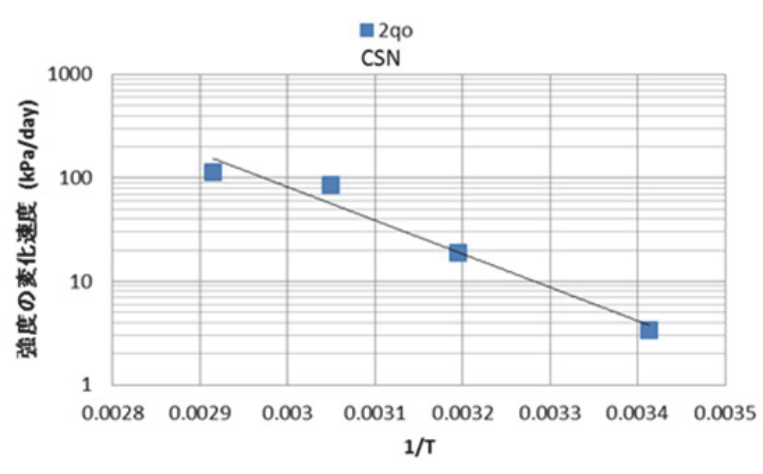

図-15 CSN＼cjkstart同形アレニウスで整理した強度の変化速度

でに有機系や酸性シリカゾル系と同様に，同型アレニウ スのプロットで $2 q_{u}$ になった強度の変化速度の測点を最 小二乗法で整理した線を図-15 に示寸。この図は，静水 養生による実験結果である。コロイダルシリカゾル系注 入材は，浸透水圧の有無に関係なくほぼ同じ強度増加を 示す．したがって，浸透水圧が作用した場合の同形アレ ニウスのプロットもほぼ同じになる.

\section{7. 結論}

1) メスフラスコを使用した方法で約 9000 日経過のゲ ル化した注入材(ホモゲル)そのものの体積変化を測定 した. 有機系注入材は約 40 日経過後までに約 5 6\%の 体積変化をしてその後ほぼ一定となる．酸性シリカゾ ル系注入材は，体積収縮期間が長く 1000 日で約 23\% の体積减少をする. 2000 日の体積减少の 95\%である. その後の体積変化はほぼ一定に值を示寸.コロイダル シリカゾル系注入材の体積変化はほとんどゼロである

2) 体積変化の違いはゲル構造の違いによるものと推測 される. 9000 日経過で 3 種類のゲル化した注入材(ホ モゲル)の体積変化は終息した. また 3 種類の注入材は 目視によるゲルの解重合が見られない，ゲルの安定は 今後もさらに継続するものと判断できる.

3）約 9000 日経過の $\mathrm{SiO}_{2}$ の溶脱率を測定した. 有機系 注入材は 1000 日経過付近までの $\mathrm{SiO}_{2}$ 溶脱は約 $23 \%$ で あった，その後は極微量な溶脱でほぼ終息する．溶脱 率は未反応シリカの $40 \%$ を超えていないことより解 重合によるシリカの溶脱はないものと判断できる. 酸 性シリカゾル系注入材は約 $2 \%$ の溶脱率で少ない.コ ロイダルシリカ系注入材は 9000 日経過後もシリカの 溶脱率はほぼゼロである。目視による 3 種類のゲル化 した注入材(ホモゲル)の解重合は見られない，今後も 安定は続くもとと推測される.

4) 本論文の各日数における全データの標準偏差の平均
值は前回の報告 ${ }^{1)}$ 上り悪かったが，各種注入固結砂の 長期強度の動向を広義に見てそのトレンドを知る必要 もあると考えデータの整理を進めた：その結果，1000 日を越える長期強度は, 3 種類の注入材とも 2000 年に 発表した論文集の予測值のトレンドにほぼ一致した。

5) 有機系注入材注入固結砂は経時的に減少をして初期 強度の約 $1 / 4$, 酸性シリカゾル系はピープ強度を付け たあと $1 / 2$ まで強度减少をするが，その後は安定を保 つ.コロイダルシリカゾル系注入材固結砂は初期強度 の 4 倍強度増加をする. 養生条件が静水養生であれば 3 種類の注入固結砂は, 本研究での最終測定強度をさ らに長期間保持できるものと推測できる.

6) 本実験では, 連続的に注入固結砂供試体に浸透水圧を 加え所定の時間が来たとき注入固結砂供試体の強度を 測定した。これによって浸透水圧が作用した場合の影 響の一部は把握できると考えて同形アレニウス法でデ 一タを整理した。 その結果，有機系およひ酸性シリカ ゾル系注入固結砂は, 静水養生に比べて強度劣化が早 くなった．これより浸透水圧は強度の劣化に影響を及 ぼすことが推定できた。 これに対しコロイダルシリカ ゾル系注入材は, 動水勾配 $i=1 ， 10$ の浸透水圧が作用 しても静水養生の経時変化と同様に強度増加をした。 耐久性注入材としての使用が期待できる.

\section{参考文献}

1) 加賀宗彦: 水ガラス系注入材の安定性と注入固結砂の 長期強度の予測, 土木学会論文集, No.652/III-51, pp.195-205， 2000.6

2) 加賀宗彦: 注入固結砂などに関連する水ガラス系注入 材のゲル構造，土木学会論文集，No.460/V-18， pp.93-102， 1993.2

3) 加賀宗彦，森 麟：薬液注入におけるゲル化した注入 材の安定性と固結砂強度の耐久性に関する基礎研究, 土木学会論文集, No.496/V-24, pp.31-40, 1994.8

4) 加賀宗彦, 米倉亮三, Rudolf ALLMANN : 水ガラス系 注入材のゲルの状態と注入固結砂の凍結特性, 土木学 会論文集，No.585/V-38，pp.3-9，1998.2

5) 加賀宗彦，菊池康裕，大坪紘一：浸透水圧が作用する 水ガラス系薬液注入固結砂の強度の耐久性, 材料学会, 第 5 回地盤改良シンポジウム論文集, pp.73-76, 2002.11

6) 高レベル放射性廃棄物処分関連・地下坑道施工技術高 度化開発報告書，独立行政法人日本原子力研究開発機 構, 2010.3

7) 金子剛，小沢丈夫 : 周期的に加熱・冷却を加えた絶縁 材料の劣化の化学反応速度論的取扱い, 電気学会論文 誌 A， 52-A14， 97 巻， 2 号，pp.48-55， 1977.2

8) 早川淨 : 高分子材料の寿命評価・予測法, アイピーシ 一, pp.183-198, 1994

9) 慶伊富長 : 反応速度論 第 2 版, pp.3-11, 東京化学同 人, 1990 .

10）地盤工学会 : 薬液注入工法の理論・設計・施工, 地盤 工学会, 2009.6

11) 米倉亮三, 島田俊介, 木下吉 : 恒久グラウト注入工法, 
山海堂, 2000.8

12) 秋田勝次, 井浦智実, 朝倉俊弘: 海底トンネルで施工 されたセメント水ガラス注入材の長期材料特性と性 能評価, 土木学会論文集, F1 (トンネル工学), Vol.67, No.2, pp.95-107, 2011.

13）平間陽，赤木寛一，澤田亮 : 薬液で改良した砂地盤の
経時変化特性について，土木学会第 65 回年次学術講 演会, 2010.9

14）長瀬迪夫 : 浸透破壊に関する考え方と破壊発生の条件 (その 2), 応用地質年報, No.15, pp.1-29, 1993.

(2012. 10. 30 受付)

\title{
DURABILITY OF THE STRENGTH OF SILICATE GROUTED SAND AND EFFECT OF SEEPAGE WATER PRESSURE
}

\begin{abstract}
Munehiko KAGA
Until now, we have examined the prediction methods of the long term strength of silicate grouted sand. However, these methods are predictions under hydrostatic curing condition. It may not be able to apply the prediction method, when seepage water pressure worked. Then, we carried out the experiments in which the seepage water pressures worked. As a result, the seepage water pressure weakened the strength of grouted sand. Next, We measured the volume change and $\mathrm{SiO}_{2}$ leaching of pure grout for 9000 days. Consequently, these stopped almost in the progress of time.
\end{abstract}

